\title{
NUP98/TOP1 Fusion Gene
}

National Cancer Institute

\section{Source}

National Cancer Institute. NuP98/T OP1 Fusion Gene. NCI Thesaurus. Code C99442.

A fusion gene that results from a chromosomal translocation $t(11 ; 20)(p 15 ; q 11)$ which fuses the first half of the NUP98 gene with exon 7 of the TOP1 gene. This fusion is associated with both therapy-related acute myelogenous leukemia and therapy-related myelodysplastic syndrome. 